\title{
РЕЦЕНЗІї
}

\section{DOI 10.31558/2519-2949.2021.4.14}

\section{ОНОВЛЕНА МОНАРХІЯ: ВИКЛИКИ ТА ЗАГРОЗИ}

Інститут монархії, який органічно і невід'ємно пов'язаний з історією Іспанії від років проголошення державної незалежності і до сьогодення, переживає у XXI сторіччі драматичні і вкрай небезпечні для долі Бурбонської династії часи. Саме цим обставинам і присвятив своє дослідження під назвою «Феліпе VI. Король у небезпеці» Хосе Антоніо Сарсалехос Ньєто, народжений 1954 року у Більбао.

Автор розпочинав свою кар'єру як журналіст, був керівником низки медійних агенцій, зокрема, редактором популярної роялістської газети $\mathrm{ABC}$, $є$ номінантом багатьох видатних іспанських журналістських премій, написав п'ять монографій, які здебільшого стосуються баскського сепаратизму, урядування Х.Л. Р. Сапатеро, життя та правління іспанських королів Хуана Карлоса I i Феліпе VI. Він також був тією людиною, яка першою ексклюзивно оприлюднила матеріали про зречення Хуана Карлоса I у червні 2014 року.

Оригінальною є структура книги. Маємо не послідовний і чіткий у хронологічному вимірі виклад матеріалу про життєвий шлях Феліпе VI, а окремих п’ять розділів («Зрада», «Два королі», «Депортація», «Знущання», «Леонор»), присвячених подіям, які найбільш виразно висвітлюють обставини дискредитації правління Хуана Карлоса I у першому десятиріччі XXI століття, загрозам, які чатують над королюванням його сина й спадкоємця Феліпе VI, та сподіванням на порятунок і довготривале майбуття іспанського корони [1, p.7]. Тональність викладу і аналізу матеріалів щодо сучасної ролі монархічної інституції в Іспанії далека від компліментарності. Автор об'єктивно і незаангажовано, хоча і емоційно, розповідає про всі конфліктні ситуації у Королівсті Іспанії, характеризує особистість і важкі обставини правління Феліпе VI, спричиненими діями його батькакороля. Х. А.Сарсалехос не ставить питання: «Чи потрібна Іспанії монархія?», а пропонує відповіді, які потребує нині іспанське суспільство, і які повинен реалізувати новий король Феліпе VI, щоб зберегти за своїми спадкоємцями іспанський трон.

У вступній частині автор вдається до історичних ремінісценцій. Проводить паралелі між двома портретами різних епох: картиною Ф. Гойї 1800-1801 років «Карлос IV Іспанський та його родина» та портретом Феліпе VI сучасного художника Ернана Кортеса, написаного 2015 року. Х.А. Сарсалехос характеризує картину Ф Гойї, на якій зображено у натуральній величині самого Карлоса IV i його чисельну родину, одягнених у нарочито помпезні шати з безліччю золотих прикрас, як зразок занепаду Бурбонів (відомо, що Карлос IV двічі зрікався корони) і портрет Феліпе VI, на якому немає жодного помпезного наслідування своїх давніх предків, жодних ознак могутності, король навіть не у військовому однострої, а у цивільному одязі : сірий костюм, краватка в лілових тонах і біла сорочка. Якщо обличчя Карлоса IV пихате і зверхнє, то молодий король виглядає спокійним, але зосередженим, заглибленим у себе, з легкою, майже непомітною, посмішкою, прихованою вусами і короткою борідкою зі сивиною. Новий король випромінює надзвичайну серйозність, поводиться елегантно. Зайняття спортом, до якого залучив i родину, підтримує його добре здоров'я і чудовий фізичний стан. Автор констатує, що цей спокійний чоловік, Феліпе VI, у небезпеці. Отримавши легітимний мандат на управління Іспанією, йому належить відновити репутацію королівської родини, інституту монархії, зберегти конституційну монархічну систему в країні, зганьблену його батьком-королем. Іспанія, стверджує автор, має великі шанси з королем-державником, яким є Феліпе VI, зможе перебороти монархічну кризу і загалом системну кризу. Ті, хто цькує нового короля, знущаються 3 нього, і сподівається на руйнацію королівства, не отримають цього, бо Феліпе VI, не чіпляючись вперто та ірраціонально за свій статус конституційного монарха, ніколи, на думку автора, не зречеться свої легітимної відповідальності, щоб передати правління не президенту республіки, а своїй спадкоємниці, принцесі Астурійській [1, p.15-25].

\footnotetext{
${ }^{1}$ Рецензія на книгу: Jose Antonio Zarzalejos. Felipe VI. Un Rey en la Adversidad. Barcelona: Editorial Planeta, S. A., 2021. $350 \mathrm{p}$.
} 
Попередимо подальше рецензування книги деякими власними зауваженнями. Король Хуан Карлос I, якого Ф.Франко призначив своїм спадкоємцем, прислужився Іспанії своїми доброчесними справами. Саме йому іспанці завдячують так званим «переходом через пустелю», тобто монархія в особі Хуана Карлоса I виступила під час демократичного транзиту ініціатором та «локомотивом» мирного демонтажу франкізму та запровадження повноцінної конституційної демократії. Король визначав стратегічні напрями та ухвалював остаточні рішення, а реалізація і важелі управління належали урядові. На першому етапі транзиту король був у відповідності з діючим франкістським законодавством головною діючою особою на політичній сцені Іспанії. Після прийняття Конституції 1978 року король відмовився від низки повноважень свого попередника, його владні функції еволюціонували від статусу головної політичної особи до арбітра та надпартійного лідера нації. Дослідники визначили форму правління Хуана Карлоса I як «немонархічну монархію» (2, с.21)

Відновлення монархічних інституцій в Іспанії в 1975 році припинило загрозливу поляризацію суспільства, безперервний ланцюг революцій, переворотів, повстань та громадянських воєн, а сам король набув в очах іспанської спільноти символічний характер справедливого захисника національної єдності держави. Саме завдяки харизмі та рішучим діям Хуана Карлоса I іспанці, чимало яких були аполітичними чи симпатизували республіканському устроєві, сприйняли монархію та іiі інституції, зокрема, через симпатії насамперед до Хуана Карлоса I, які отримали назву «хуанкарлізму» (Див.: детальніше: (2, с. 16-23).

Проте у 2011-2014 роках династія Бурбонів в Іспанії опиналсь через низку скандалів, у тому числі корупційних, учасником яких був Хуан Карлос I, на грані втрати довіри своїх співвітчизників. Цілковите непорозуміння та здебільшого гнів іспанців викликала звістка про те, що у квітні 2012 року в умовах економічної кризи, яка спіткала країну, коли кожен другий іспанець був безробітним, вже немолодий і обтяжений хворобами король у супроводі привабливої жінки та суадівського принца поїхав у Ботсвану полювати на слонів (42 тис. євро за кожного вбитого слона). Можливо, ця подія залишилась би втаємниченою, якби король, падаючи, не зломав шийку бедра і його спеціальним рейсом відправили назад до Іспанії.

Жінка, яка супроводжувала короля, це німецька принцеса Корінна цу Сайн-Вітгенштейн у дівоцтві Корінна Ларсен. Хуан Карлос I познайомився з Корінною Ларсен за десять років до свого зречення, йому було 66, а їй 39. Корінна не була обтяжена моральними перепонами, знала п'ять мов і від французької компанії Boss організовувала послуги багатим любителям екзотичного відпочинку. Нове кохання заполонило старіючого короля. Жіноче товариство завжди вабило Хуана Карлоса I. Він зраджував королеві Софії. Але іспанці поблажливо дивилися на ці витівки свого улюбленця-мачо (Див.: детальніше: 3, с.247-276).

Тепер він відкинув всі умовності: були таємні зустрічі у помешканнях друзів і в дорогих отелях, приватні подорожі на приватних літаках по світу за рахунок своїх симпатиків. Хуан Карлос I навіть поселив свою коханку в апартаментах в околицях Сарсуели (резиденції королівського подружжя).

Варто зауважити, що в європейських королівських домах вистачало скандалів - особливо адюльтерних. Але корупційні скандали, які приписували іспанськму королю, це безпрецедентне явище. Іспанський король порушив неписаний кодекс монаршої честі та гідності.

До цього безпрецедентного скандалу додався інший, пов'язаний з корупційними діями зятя Хуана Карлоса Іньякі Урдангаріна, герцога Пальма-де-Майорського, гранда Іспанії, у причетності до яких підозрювали і самого короля. Колишній спортсмен Іньякі був членом національної збірної Іспанії з гандболу. Згодом очолив благодійний фонд Ноос, який займався організацією спортивних змагань Кримінальна справа проти Іньякі була відкрита у 2010 році. Йому інкримінували нецільове використання упродовж 2005-2006 років 2,3 млн. євро. Ці кошти, за результатами слідства, були переведені на рахунки компаній, які контролювались герцогом, та на офшори. Судовий процес над королівським зятем розпочався у лютому 2012 року. Його дружину, інфанту Крістіну, також звинувачували у податкових злочинах і відмиванні грошей. Вона була першим членом королівської родини, яка давала свідчення у суді у справі свого чоловіка. Іньякі опинився у 2018 році за гратами, а інфанту Крістіну виправдали. Проте вона повинна була сплатити штраф. Обох, і Іньякі та Крістіну, Феліпе VI позбавив титулів герцога і герцогині Пальма де Майорка.

Невдоволення поведінкою Хуана Карлоса I набирало небачених масштабів і спрокувало конституційну кризу в країні. Проте король, за даними автора, який ще у лютому 2013 року писав про можливе зречення короля, втрачав зв'язок з реальністю. Ті, хто оточував Хуана Карлоса I, а саме: друзі-бізнесмени, друзі-яхтсмени, відставні військовики та інші, запевняли його, що він став жертвою брехні, переконували його унеобхідності у подальшому керівництві державою, До того ж, 
хуанкарлістськи налаштовані 3МI, директори та редактори журналів та газет, з якими Хуан Карлос I заприятелював ще на початках свого королювання, здійснювали політику, названу «пактом мовчання», прикриваючи оборудки короля-приятеля. Не дивно, що у його планах не було зречення. У дипломатичних колах, стверджує дослідник, згадують, що на останній зустрічі з королем Марокко Хасаном II, іспанський король гаряче запевняв свого візаві, що «ніколи» не зречеться [1, p.60]. Дехто вважав, що монарх був напередодні зречення не зовсім «притомним». Х. А. Сарсалехос підтверджує це, описуючи останній офіційний візит короля у травні 2014 року, за місяц до зречення, до країн Перської затоки (ОАЕ, Кувейт, Саудівська Аравія, Оман, Бахрейн), який викликав потужний політичний та медійний інтерес. Цей епізод доводить, що король все-таки усвідомлював свою ситуацію і передбачав, що йому, можливо, буде згодом потрібна допомога монархій Затоки.

2 червня 2014 року Хуан Карлос I, не витримавши тиску та критики, які охопили іспанську спільноту, та можливості започаткування Верховним судом карної справи щодо нього, оголосив, що зрікається корони на користь свого сина Феліпе. У промові з нагоди зречення він мав останню нагоду визнати свою відповідальність перед народом, попросити вибачення, який, будучи іспанським, прийняв би його каяття. Та король лише говорив про деякі помилки, колективізував свої гріхи, кажучи «ми» замість «я», що роздратувало навіть тих, хто ставився до нього доброзичливо. Х.А.Сарсалехос називає ці дії короля-емерита «зрадою» іспанців і «зрадою» свого сина. Журнал «The Economist» відгукнувся на зречення іспанського короля такою фразою: «Новий король Феліпе успадкує пошкоджену країну і корону. Його завдання полягає у тому, щоб вдихнути у корону те почуття гідності, яке сучасні іспанці продемонстрували у часи великих труднощів» [1, p.80-81].

19 червня 2014 року кортеси оголосили Феліпе VI королем Іспанії, який тут же присягнув на вірність Конституції. Король-емерит був відсутній на цій парламентській церемонії.

X.А.Сарсалехос називає Феліпе VI «гіпотетичним королем», оскільки він небагатослівний, не дає безлічі інтерв'ю, як робив його батько, комунікації із журналістами відбуваються в умовах конфіденційності, а не в атомосфері панібратства. Також відсутні його офіційні біографії, хоча відомі всі аспекти його життя: де навчався., яку і де магістерську захищав, його навчання у військових закладах, деякі приємні родинні епізоди. Але, автор вважає, що вони недостатні для того, щоб пояснити умови його формування як особистості і як короля. Феліпе VI висловився якось, що коли у нього виникають сумніви, то він береться за Конституцію і не відпускає іiі, поки не зникнуть будьякі сумніви. Новий король вважає, що і так є досить знаним для іспанців у контексті виконання ним найвищої ролі у державі, а мета корони полягає, окрім доброчесності ії очільника, у якісному виконанні його конституційних функцій, у відновленні того, що його батько вибудував і врешті-решт зруйнував. Якщо його батько хвалився своєю веселістю і свійкістю, притаманною Бурбонам, то Феліпе VI отримав прізвисько «підготований», тобто він насправді інтелектуально й культурно готовий для виконання своїх обов'язків. Він $є$ поліглотом, інтенсивно збирає інформацію, щоправда, більше цікавиться аналітикою, аніж новинами, самостійно готує всі свої виступи. Надто працьовитий, читає і перечитує повідомлення, просить роз'яснення у різних спеціалістів, радіє від пізнання нового, щиро слухає і спілкується годинами, не переймаючись плином часу, з політиками, вченими, іншими фахівцями. Звідси він уникає того, що медіа можуть транслювати надумані розбіжності і неоднозначні оцінки. Хтось сказав, що «новий король якраз і призначений для правління у найбільш складний момент історії Іспанії» [1, p.15, 27-28, 30, 32].

Ще з підліткового віку Феліпе був свідком родинних розладів, переживав суперечливі почуття до батька - від захоплення ним як державним діячем і до розчарування через його численні зради i ставлення до матері, до якої син-король відчуває глибоку ніжність та вдячність. Водночас Феліпе може приймати неортодоксальні рішення, як, наприклад, його морганатичний шлюб з Летицією Ортіс у 2004 році.

X. А. Сарсалехос зазначає, що Іспанія після зречення Хуана Карлоса I пройшла через серйозні випробування, які віддзеркалились у тому, що почуття тривоги й занепокоєності стали загальнонаціональною тенденцією. 32015 по 2019 роки відбулося чотири тури парламентських виборів, зміна декількох урядів. Через це діяльність нового монарха Феліпе VI фактично була паралізована. На правління Феліпе VI припала руйнація двопартійної політичної системи, коли у роки Хуана Карлоса I дві партії - соціалісти та народники - поперемінно змінювались при владі. До того ж між Хуаном Карлосом I та лідером ІСРП Ф.Гонсалесом існували довірчі стосунки.

Тепер же завершилась епоха однопартійних урядів і в складних умовах формуються коаліційні уряди. Комунікація між Монклоа (резиденція уряду) і новим королем налагоджувалась складно. Цьому сприяла, окрім вищенаведених фактів, і провокативна діяльність короля-емерита Хуана 
Карлоса І. Він продовжував і після зречення провадити публічну діяльність, яка непередбачена законом, здійснює приватні подорожі до країн Перської затоки (чотири з часу зречення), проводить зустрічі та дає інтерв'ю журналістам іноземних агенцій тощо. Такі часті вояжі до арабських країн і поведінка Хуана Карлоса I викликала серйозний спротив в уряді, вороже ставлення до короляемерита іспанських ЗМІ. До того і після зречення Хуан Карлос I своїм королівським указом від 13 червня 2014 року зберіг за собою і своєю дружиною, королевою Софією Грецькою, всі почесті і титули королів. Король-емерит продовжував проживати в офіційній резиденції іспанських королів, в Сарсуелі. Х.А.Сарсалехос присвятив цим подіям цілий розділ під назвою «Два королі».

Отримавши попереднє схвалення уряду, Феліпе VI вирішив покінчити з цією парадоксальною ситуацією після останнього інституційного заходу у грудні 2018 року за присутності короля і королевиемеритів з нагоди 40-ї річниці з часу прийняття Конституції 1978 року. Проте сам батько-король випередив свого наступника. Він написав синові-королю листа, в якому сповіщав, що 32 червня 2019 року припиняє будь-яку інституційну діяльність. Уже через п’ять днів своїм королівським указом син-король ліквідовує секретаріат свого батька, зменшує ескорт і використання офіційних автомобілів, забороняє приймати будь-які офіційні запрошення на візити та зустрічі. Автор рецензованого нами ж дослідження називає ці події «другим зреченням» Хуана Карлоса I (1, p.130.).

Проте, за даними Х.А. Сарсалехоса, причиною цього була інша вражаюча причина. У червні цього ж року (5 і 8 червня) адміністрація королівського дому отримала два листи 3 британської адвокатської контори, в яких повідомлялось, що Феліпе VI фігурує як 2-й, а його донька, принцеса Астурійська, як 3-й бенефіціар, створеного у 2018 році королем-емеритом фонду для приховування внеску, зробленого Саудівською Аравією, на суму 100 млн. Ці кошти перебували до 2012 року на рахунках у швейцарському банку, допоки Хуан Карлос I не перевів останні 65 млн. дол. у вересні цього ж року Корінні Ларсен, своїй коханці, з якою Хуан Карлос I розірвав стосунки і яку Сарсуела (королівська резиденція) вважала «ворогом» для інституту монархії (1, p.131). Ці листи були переслані також секретареві королеви-консорта Летиції. Найголовніше все ж полягало в тому, що король-емерит не сплатив належних податків. Швейцарська фінансова поліція вже декілька років вела таємне розслідування щодо коштів Корінни Ларсен, підозрюючи ії у відмиванні грошей. Хуан Карлос I неодноразово відмовлявся через свого адвоката коментувати ці звинувачення.

Відповідь Феліпе VI була наступною: він за себе і старшої доньки відмовився від коштів фонду, створеного підставними особами для його батька. Але громадськості це не повідомлялось. До речі, до 18 червня 2014 року король-емерит володів імунітетом від карного переслідування.

За декілька днів до отримання листів від британських адвокатів родич короля Альваро де Орлеанс-Бурбон дав інтерв”ю газеті «Ель Паїс», яке мало слугувати громовідводом і заспокоїти громадськість, натомість зіграло роль «бомби», яка «вибухнула». Він визнав, що оплачував багато приватних перельотів Хуана Карлоса І.. Фонд «Загатка», ним створений у 2003 році, не належав Хуану Карлосу I, але оплатив 8 млн. дол. за прогулянки короля з Корінною. Він також заперечував отримання 39 млн. ф.ст. за посередництво у продажі одного із сарагоських банків.

У вересні 2018 року колишня подруга Хуана Карлоса I Корінна Ларсен заявила, що він отримав комісійні у зв'язку з протекцією щодо будівництва іспанськими компаніями залізниці між Меккою та Медіною.

9 грудня 2020 року король-емерит добровільно вирішив врегулювати проблему з несплаченими податками і сплатив належні податки. Ця акція дещо пом'якшила адміністративні та каральні заходи щодо Хуана Карлоса, але публічний осуд за ухилення від сплати податків людиною, яка була главою держави, дійшов свого апогею. До того ж 14 березня 2020 року британська газета «Санді Телеграф» оприлюднила матеріали про офшорний фонд короля-емерита, пов'язаного з подарунком Саудівської Аравії. Ці прикрі події розгортались на фоні коронавірусної пандемії, яка стрімко поширювалась по країні.

Ця інформація лягла тінню і на імідж короля Феліпе VI і ширила сумніви у його доброчесності. Новий король звернувся 3 промовою до нації, в якій заявив, що «корона повинна піклуватись про гідність інституції, берегти ії престиж і дотримуватись чесної та прозорої поведінки, які відповідають іiї інституційній функції і відповідальності перед народлом. Лише таким чином монархія, твердив Феліпе VI, матиме моральний авторитет, необхідний для здійснення своїх функції. Сьогодні, як ніколи раніше, громадяни 3 повним правом вимагають, щоб моральні та етичні принципи надихали, а зразкова поведінка панувала у нашому громадянському житті. Король, який очолює державу, має бути не лише прикладом для наслідування, але й служити цій справедливій і законній вимозі громадян» (1, p.138). 
За цим послідували дії короля: 1) відмова від спадку батька-короля, який належить йому особисто, а також від будь-яких активів, інвестицій чи фінансових структур, походження яких не відповідають законності чи критеріям доброчесності; 2) позбавлення короля-емерита асигнувань з бюджету у розмірі 194 тис. євро щорічно; 3) заперечення у причетності до будь-яких фондів та участі в них самого Феліпе VI і його доньки-спадкоємниці; 4) направлення листа, завіреного нотаріусом, батьку-королю з вимогою анулювати призначення, якщо таке $\epsilon$, його та онуки Леонор бенефіціарами будь-яких фондів; 5) розпуск секретаріату короля-емерита.

Ця промова та заходи Феліпе VI вразили іспанську спільноту, пригічену пандемією та нестачею лікарняних ліжок, і мали масштабні наслідки для іспанської корони. Насамперед це означало остаточний розрив з батьком-королем та констатацію невдачі його зречення як запобіжника для захисту корони. Разом з тим своїми діями Феліпе VI підтвердив, принаймні дотично, правдивість фактів, наведених вище. У дебатах один із професорів-юристів визнав, що через недоторканість, яка надається королям, Іспанія матиме «монарха-злочинця» $(1$, p. 143). Хуан Карлос I визнав, що не проінформував сина про два фонди: Лукум і Загатка, якими приховувались його непрозорі оборудки.

В обстановці абсолютного потрясіння, яке охопило оточення Феліпе VI та чимало іспанців, виникає ідея про те, що батько монарха має покинути Сарсуелу і навіть Іспанію. X. А.Сарсалехос зазначає, що упродовж шести років після зречення батька, правління Феліпе VI позначене безперервними прийняттями рішень, які підтверджують його мету оновити монархію, підняти іiі до найвищих щаблів належної репутації і респектабельності. Він зменшив кількість членів королівської родини (король і королева, його батьки і їхні дві доньки), скасував герцогські титули своєї сестри, інфанти Крістіни та ії чоловіка, яка не відмовляється від прав на спадкоємність у той час, коли ії чоловік відбуває покарання за гратами, та указ батька про зняття судимості з низки осіб з нагоди 40-ї річниці Конституції, позбавляє батька державних асигнувань, відмовляється разом із донькою від будь-якого батьківського спадку.

Тим часом в оточенні нового короля, в іспанській спільноті, політичних та правових колах шириться ідея імпічменту проти короля-емерита, притягнення його до судової відповідальності та ідея його екстрадиції. Так намагалися врятувати корону від повної руйнації. Важливу роль у цій кампанії зіграв прем'єр-міністр Педро Санчес, який назвав інформацію про короля-емерита «такою, що викликає стурбованість і занепокоєння». У прем'єрській заяві слова «потрясіння», «порушення порядку та спокою», необхідність «змін» вплинули на короля-емерита. Хоча він вважав, що відповідальними за його висилку з країни, були прем'єр-міністр П.Санчес, керівник королівської адміністрації та королева-консорт Летиція. Частина ЗМІ звинувачувала Феліпе VI у нерозсудливій пасивності, глузувала з нього. I цим сприяла поширенню республіканізму. Інша частина - писала, що будь-які дії, спрямовані проти Хуана Карлоса I, започатковують ліквідацію монархії в Іспанії [1, p.154-155].

Х.А.Сарсалехос детально описує у розділі «Депортація», як керівник королівської адміністрації Хайме Альфонсін спілкувався з Хуаном Карлосом I з метою переконати його заради порятунку Корони у необхідності від'їзду з країни. Необхідно було, щоб таке рішення прийняв сам корольемерит. Врешті-решт, король погодився на таке рішення, поставивши умови: він сам обирає країну, до якої емігрує; вільно пересуватиметься по світу; повідомлення про його місцезнаходження можливе лише тоді, коли він дозволить секретаріату нового короля оприлюднити ці відомості. Він також надав адресу контори свого адвоката для отримання судових та адміністративних повідомлень. Оприлюднення повідомлення про від’їзд з країни Хуана Карлоса I було обрано спеціально, а саме, у місяці літніх відпусток 2020 року, коли спала перша хвиля пандемії, а провідні журналісти та ведучі популярних теле- та радіопередач були у відпустках.

X.А. Сарсалехос пропонує детальну хроніку цих драматичних для короля-емерита днів. 1 серпня Хуан Карлос I зателефонував своєму близькому другу Педро Кампосу Кальво-Сотело, голові Королівського яхтклубу, і повідомив, що 2 серпня він покидає Сарсуелу і їде у напрямку Понтеведри, плануючи перепочинок у його помешканні. 3 Педро Кампосом батько-король заприятелював ще у 1982 році. Їх зблизила любов до моря, рибалки та яхтового спорту. Король виїхав з Мадриду на зеленому позашляховику, заправленому такою кількістю пального, щоб по дорозі не виникла потреба дозаправки машини. Його супроводжував невеликий ескорт. Другу половину дня 2 серпня король провів у товаристві родини свого приятеля. Наступного дня, 3 серпня, король 3 малопримітного аеропорту Віго вилетів на приватному літаку, який без пересадок доставив його до Абу-Дабі. Коли в Іспанії оголосили про від’їзд короля, а це сталося аж 17 серпня, він вже знаходився в ОАЕ. Було оприлюднено і лист батька-короля до сина, короля Феліпе VI, в якому він зізнається, що у даний момент не приніс синову ні спокою, ні миру, і що його подальше перебування 
в Іспанії спричинює неспокій, і він хоче допомогти своєму сину-королю у відповідальному виконанні ним королівських функцій. Хуан Карлос I запевник сина, що його від'їзд - це його особисте і зважене рішення, яке він прийняв 3 «глибоким жалем», але і водночас зі «спокоєм». 3 контексту листа зрозумілј, що король покидає батьківщину тимчасово. Адміністрація королівського дому відповіла спеціальним зверненням, в якому син-король висловив вдячність батькові і «свою повагу» до нього. Текст звернення закінчувався словами про «історичну важливість» правління батька і запевненням, що король-син буде суворо дотримуватись Конституції і тих принципів і цінностей, на яких базується іспанська корона [1, p.168-175].

По-різному поставились в Іспанії до від’їзду Хуана Карлоса I. Одні назвали це «втечею»; другі висловлювали повагу до його рішення, яке $\epsilon$ виваженим і особистим, він не переховується, коли його покличуть, то він повернеться; треті - що король повернувся на місце «злочину» [1, p.176-179].

3 рецензованого дослідження з'ясовуємо, що король-емерит поселився на віллі, яку охороняють і контролюють спецслужби Еміратів. Він може гуляти і проводити час на свіжому повітрі. Так само відомо, що існує також іспанська група охорони, ротація якої відбувається через кожні 15 днів, і яка оплачується іспанським МВС. Телефонне спілкування Хуана Карлоса I захищене від будь-якого втручання. Автор вважає, що у жодній іншій країні король-емерит не отримав би такого безпечного і комфортабельного прихистку, ніж в Абу-Дабі. Деякі родичі мають можливість відвідувати короля. Його старша донька, інфанта Єлена, вже двічі гостювала у батька [1, p.179-182].

Чутки про можливе повернення короля-емерита час-від-часу з'являються в іспанских 3МI. Але видається, якщо його експатріація є малозрозумілою, то повернення, запевняє автор, матиме ще гірші наслідки [ 1, p. 183].

В останньому розділі під назвою «Леонор» Х.А. Сарсалехос пов'язує майбутнє іспанських Бурбонів із наступною і єдиною спадкоємницю іспанської корони, старшою донькою короля Феліпе VI і королеви Летиції, принцесою Астурійською, Леонор де Бурбон і Ортіс, яка народилася 31 жовтня 2005 року в Мадриді. На час написання книги їй виповнювалось 16 років. Вже у такому юному віці принцеса Астурійська володіє, на думку автора, харизмою, так необхідною для осіб королівського походження. Упродовж 2019-2020 років іспанці переконались уії спокійному характері, у відповідальному розумінні й серйозному ставленні до своєї майбутньої ролі як спадкоємниці корони. Королі-батьки не допускають жодної імпровізації у вихованні своїх доньок - принцеси Астурійської та інфанти Софії. Вони зробили ставку на сімейне виховання своїlх доньок. У родині панує атмосфера любові, приязні, поряд з якими є належна дисципліна та вимогливість. Королівське подружжя налагодило щиросердечні стосунки з доньками, прагнучи уникнути повторення суперечок і непорозумінь, як це сталося у родині Бурбонів-Грецьких. Сестри ростуть веселими дівчатками, 3 нормальною для їхнього віку поведінкою. Проводять час із однокласницями та іншими дітьми, ходять на вистави та виставки, у магазини. Щоправда, стараються робити це інкогніто, не афішуючи себе і уникаючи фотографувань.

Це також стосується навіть імені Леонор. Якщо Феліпе назвали на честь його далекого попередника Феліпе $\mathrm{V}$, щоб уникнути негативних асоціацій з іменами нинішніх найближчих родичів, то ім'я принцеси запозичене від імені наваррської королеви XV століття, як найменш скомпрометованої серед інших попередніх іспанських королев.

Леонор та Софія відвідують світську школу (у світоглядному сенсі - католицьку), у якій навчвся їхній батько-король. Школа закцентована на вивчення мов, на новітні технології, спорт. Леонор вивчає англійську і французьку мови, одночасно з каталонською та арабською. Захоплються природничими науками, зокрема, фізикою. Хоча вивчатиме юриспруденцію, гуманітарні, економічні науки, військову справу, які необхідні для виконання нею майбутніх королівських обв'язків.

Повноліття прицеси Астурійської припадає на 31 жовтня 2023 року. Ця дата збігається із закінченням повноважень кортесів 24-го скликання. Ймовірно, ще перед нинішніми кортесами i батьком-королем Леонор складе присягу і таким чином буде формалізованао ії статус повноцінної спадкоємниці іспанської корони.

В останні місяці 2021 року принцеса Леонор демонструє свою яскраву самобутність i харизматичність, беручи участь у низці публічних заходів, які відповідають початковому етапу діяльності спадкоємниці корони (церемонія вручення премій принцеси Астурійської; відзначення річниці Конституції; доповідь каталонською, англійською та арабською на врученні премій фундації принцеси Хіронської; нагородження її королем Феліпе VI орденом Золотого Руна). Іспанські і зарубіжні медіа пишуть про те, що принцеса вражає своєю чарівністю, благородною поведінкою, простою, хоча вишуканою, але без пафосу, розмовою, володіння нею певними ораторськими 
техніками (це заслуга, більш всього, королеви Летиції, як колишньої журналістки). Британська «Дейлі Мейл» назвала принцесу Астурійську « королевою, яку очікують».

Щоправда, зазначає автор, майбутнє іспанської монархії є найбільш абстрактним. Не можна стовідсотково стверджувати, що Леонор стане королевою. Якщо Феліпе VI вдасться зруйнувати «довгий хвіст» ганебних вчинків свого батька-короля Хуана Карлоса I, який роз’їдає довіру іспанців до монархічної інституції, витримає тиск на неї з боку республіканців, лівих популістів, баскських та каталонських сепаратистів, захистить і модернізує існуючі державні інституції, переборе кризу іспанської територіальної моделі, i, таким чином, подолає системну кризу монархічного устрою, то принцеса Леонор легітимно отримає естафету від свого батька, короля Феліпе VI і неодмінно буде королевою Іспанії.

\section{Бібліографічний список:}

1. Jose Antonio Zarzalejos. Felipe VI. Un Rey en la Adversidad. Barcelona: Editorial Planeta, S. A., 2021. $350 \mathrm{p}$.

2. Іваницька О.П. Інститут монархії як гарант демократичного транзиту в Іспанії. Політичне життя. 2021. № 2. C. 16-25.

3. Іваницька О.П. Хуан Карлос І: шлях до корони: монографія. Вінниця: ТОВ «ТВОРИ», 2019. 360 с.

О. П. Іваниџька - доктор історичних наук, професор, Донеиький національний університет імені Василя Стуса. 